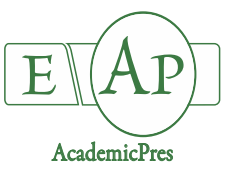

Goreeva V et al. (2020)
Notulae Botanicae Horti Agrobotanici Cluj-Napoca 48(2):1005-1016
DOI: $10.15835 /$ nbha48211895
Research Article

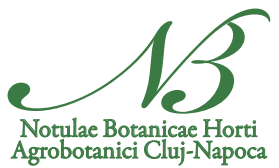

\title{
Response of oil flax varieties to abiotic conditions of the Middle Cis-Ural region by formation of seed yield
}

\author{
Vera GOREEVA*, Elena KOREPANOVA, Ildus FATYKHOV, \\ Chulpan ISLAMOVA
}

\author{
Izhevsk State Agricultural Academy, Department of Crop Production, 11 Studentskaya street, 426069, Izhevsk, Russia; \\ vn.goreeva@rambler.ru("correspondingauthor);k_evital@rambler.ru; fatykhov.il@rambler.ru; chulpan.islamova04@rambler.ru
}

\begin{abstract}
Studying the reaction to the abiotic conditions of the Middle Urals in 16 varieties of oil flax will allow to adapt the culture: increase its productivity and product quality. As a standard, the variety 'VNIIMK 620' was sown. The experiments were laid on sod-podzolic medium loamy soil in the grain-grass rotation after winter crops during 2012-2015. During the years of research, the plow layer of the experimental plots had different humus contents - medium and high, mobile phosphorus and exchange potassium - medium and very high, exchange soil acidity - slightly acidic and close to neutral. To a greater extent, by $91.5 \%$, the change in the seed yield of the studied oil flax varieties depended on the abiotic conditions of the growing season; the share of the influence of the genotype of the variety in the formation of seed yield was 3.0\%. Meteorological conditions during the years of the experiments were characterized by large fluctuations in the average daily air temperature and the amount of precipitation that fell over the months, in consequence of this the seed yield of flax oil varied in wide range over both varieties and years of study. The most favorable abiotic conditions for the formation of oil flax seeds were formed in 2014, when, during the ripening period of the seeds optimal meteorological conditions have developed with hydro thermic factor of 1.0. This contributed to obtaining the highest seed yield in $2014-218 \mathrm{~g} / \mathrm{m}^{2}$. On average, over four years of research, the same response to abiotic conditions with seed yield was formed in 'VNIIMK 620' varieties from Russia, 'Clark' varieties from Holland and 'Barbara' from Hungary. The most plastic grade is 'Clark' with a plasticity coefficient bi $=1.33$. The most stable seed yield is the 'Norlin' variety with a stability coefficient of 32.2. Russian varieties 'LM-96', 'N 3829' and foreign varieties 'Norlin', 'Atalante' proved to be the most adaptable to cultivation conditions in the agroecological conditions of the Cis-Ural region and can be considered promising in terms used as starting material in the breeding process.
\end{abstract}

Keywords: abiotic conditions; 'Atlane'; Middle Ural; 'Norlin'; oil flax

\section{Introduction}

Variety is an indicator of the hereditary properties of field crops, their characteristics of biology in the form of some advantages and disadvantages (Zhuchenko, 2008). The role of the variety is especially high in areas with extreme soil and climatic conditions for crops (Zhuchenko, 2008). For most of crops yield depends 
on unregulated environmental factors for $60-80 \%$ and above all on meteorological conditions which are not always possible to accurately predict (Tavarini et al., 2016). The less suitable and more diverse the existing environmental conditions the less likely they are technogenic regulation and the greater the role of the variety in the utilization of environmental factors and the ability to counteract the effects of abiotic and biotic stressors (Zhuchenko, 2008). The main and primary environmental factors are temperature, humidity and light (Zhuchenko, 1990). The listed factors are the main in the degree of influence on the growth and development of flax plants and in their variability (Zhuchenko, 1990). Stress factors are the main reasons for not only the large discrepancy between the average and maximum yields of field crops but also the strong dependence of the size and quality of the crop on weather changes. The variety forms the greater productivity the more it can respond by increasing quantitative and qualitative values of the crop to continuous improvement of the external environment (Zhuchenko, 2009). Varieties used in modern production must provide not only the highest yield and high-quality products but also resist adverse environmental factors, i.e., have high adaptive properties and high homeo-staticity (Shcherbakov, 1981; Rozhmina, 2001). Stable productivity in different ecological and geographical conditions can be ensured only by high adaptability of the variety which is due to its genotype (Potanin et al., 2014).

Analysis of scientific research on a global scale, namely in Russia, Canada, Ethiopia (Rossielle and Hamblin, 1981; Fu et al., 2002; Kulma et al., 2015) proves the importance of distributing the genetic diversity of cultivated plants in different countries, including flax for optimizing the selection and choosing the best samples on economically valuable traits. The resulting range of characters is of strategic importance for the conservation of genetic diversity and the efficient use of the gene pool in breeding. Significant genetic similarities between flax varieties from Russia and other European countries have been established. The results of the common origin of flax varieties from Russia are also confirmed by an analysis of their genealogy (Rossielle and Hamblin, 1981). The use of different types of flax for hybridization, including wild ones, can diversify the genetic material of newly created hybrids. All this will contribute to the manifestation in the varieties of valuable economical and biological traits, reduce stress under adverse abiotic conditions, increase yield and product quality (Fu et al., 2002; Kulma et al., 2015).

Flax is a multi-purpose culture, it is grown in many countries of the world and is becoming more widespread both in the world and in Russian agriculture. The level of yield of seeds of oil flax varieties in the conditions of the Middle Cis-Ural region varies significantly over the years and varies from 4,1 dt/ha to 12,3 $\mathrm{dt} / \mathrm{ha}$ (Fatykhov et al., 2014; Goreeva et al., 2015; Korepanova, 2016; Korepanova et al., 2017). This crop is relatively demanding on abiotic conditions; therefore, adaptively significant and economically valuable traits have specific responsiveness (reaction) to the action of environmental factors. The large scale of seed yield over the years is associated with the characteristics of the continental climate of the Middle Cis-Ural region. Therefore, the issues of early maturity and drought tolerance are topical for flax growing in the Middle CisUral region. Early ripe varieties are relatively less demanding on soil fertility, more effective than varieties of other ripeness groups using winter-spring moisture reserves in the soil to form a crop. In the conditions of the Republic of Belarus, early ripening varieties, when planted in optimal time, allow to carry out the bulk of the work when harvesting flax in late July - early August, thereby reducing the load during the harvesting period (Khamutovsky and Kargopoltsev, 2005). The cultivation of early ripening flax varieties in Western Siberia creates favorable conditions for harvesting in optimal terms which reduces the probability of large range of variation in yield (Kapinos and Leshchenko, 2009).

Scientific research on the reaction of oil flax varieties to abiotic conditions in the Middle Cis-Ural region has not been carried out. In this regard, the relevance of the studies presented is undeniable.

The greatest value for production will be those varieties of flax oil, in which the average yield and quality of seeds are at higher level, as well as in different conditions of growth and development, the signs fluctuate are on a smaller scale. Therefore, the assessment of environmental plasticity and stability of varieties of oil flax of different ecological and geographical origin is important for production and science. 
The purpose of the research is to study how oil flax varieties of different ecological and geographical origin reacts to the abiotic conditions of the Middle Cis-Ural region with the formation of seed productivity.

Research objectives:

- to determine the proportion of varieties and abiotic conditions by the impact on productivity, using data on the yield of seeds of different varieties of oil flax;

- evaluate the adaptive properties of varieties of oil flax.

\section{Materials and Methods}

\section{Object of study}

The experimental data were obtained in 2012-2015 in SC "Uchkhoz Iyulskoye ISAA", carrying out experiments on the experimental field. For the object of research 16 varieties of oil flax of various ecological and geographical origin were taken from the national collection of the All-Russian Research Institute of Flax (Torzhok): VNIIMK 620, Voronezhsky, LM-96, N3829, LM-92, Severny, Stavropol Territory, LM-98 - from Russia; Norlin and Flanders - from Canada; Atalante and Linda - from France; Mo Eregor and Barbara - from Hungary; Culbert - from the USA; Clark - from Holland. The VNIIMK 620 variety was adopted as the standard, which was entered into the State Register of Selection Achievements and approved for use in the Volga-Vyatka region (State register of selection achievements approved for use, 2020).

\section{Research methodology}

According to the methodology of conducting field agrotechnical experiments with oil crops (2010), the repetition of options in the experiment was three-fold and the seed application rate was 5,6 million germinating seeds per $1 \mathrm{ha}$. The method of sowing seeds is raw seeding for a 3-4 cm depth. The registration area of the plot is $1,05 \mathrm{~m}^{2}$. The experiment was carried out in grain-grass rotation after winter crops. The cultivation technology was consistent with the zonal recommendations for the cultivation of oil flax (Goreeva, 2019). Every year before sowing in order to calculate the doses of mineral fertilizers the agrochemical parameters of the plow layer were determined according to generally accepted methods [Workshop on Agrochemistry, 2008]. Significant differences in experiment variants were established using analysis of variance methods (Dospekhov, 2012), on years of research - in replicates, on average over the years of research, the indicators averaged over all years of the experiment for each repetition in all variants were calculated according to Vaulin (1998). For this the significance of differences ( LSD $_{05}$ ) of variants (varieties) was evaluated using the F-criterion (Fisher LSD). If $\mathrm{F}_{\text {fact }}>\mathrm{F}_{\text {theor, }}$, then there are significant differences between the compared varieties, when $\mathrm{F}_{\text {fact }}<\mathrm{F}_{\text {theor }}$, then the differences are insignificant and the null hypothesis about the equality of the compared options is not rejected. Based on two-way analysis of variance, the influence of the genotype, environmental factors, and their mutual action were determined (Dospekhov, 2012). Yield variability versus average experience or coefficient of variation $(\mathrm{V})$ was calculated according to Dospekhov (2012). Coefficient of variation (V) is standard deviation, expressed as a percentage of the arithmetic mean of a given population (Dospekhov, 2012). Variability is considered insignificant if the coefficient of variation does not exceed $10 \%$, medium - if the coefficient $\mathrm{V}$ is 11 $20 \%$ and significant if $\mathrm{V}$ is more than $20 \%$.

Calculation of environmental plasticity (bi) and stability (S2di) parameters according to the guidelines of Eberhart and Russel (1996), using the calculation method of Zykin (2005). The plasticity coefficient (bi) shows the response of the variety to changing cultivation conditions. The higher its value (bi $>1)$, the greater the responsiveness of this variety. Direct dependence of productivity on weather conditions is indicated when bi equals to 1 . The stability coefficient (S2di) is the deviation of the actual yield from theoretically possible when testing the variety. Varieties are stable if changing of environmental conditions does not affect the development of traits. The resistance of the varieties to stress and the average yield in contrasting environmental conditions (genetic flexibility) were determined according to the equations of Rossielle and Hamblin (1981). 
The level of stress tolerance of varieties is determined by the difference between the minimum and maximum productivity (Y2-Y1). This parameter has a negative sign. The smaller the gap the higher the stress tolerance of the variety and the wider the range of its adaptive capabilities. The indicator of genetic flexibility $(\mathrm{Y} 1+\mathrm{Y} 2) / 2$ reflects the average crop yield in contrasting (stressful and non-stressful) conditions and describes the compensatory ability of the variety. Degree of correspondence between the genotype of the variety and various environmental factors increases while increasing the indicator of genetic flexibility. The yield range was calculated by Zykin et al. (2000), this indicator characterizes the variation in productivity in different environmental conditions. The lower the yield range, the more stable the object in specific cultivation conditions.

\section{Soil conditions}

All years of research the experiments were carried out on sod-podzolic soil, with a granulometric composition of medium loamy soil. In the arable layer soil in different years had medium and high humus content (2.6-2.7\%); from medium to very high content of mobile phosphorus and exchange potassium (156371 and $189-313 \mathrm{mg} / \mathrm{kg}$ of soil respectively); exchange acidity of soil is weakly acidic and close to neutral (5.25.7). Based on these doses of mineral fertilizers in the years of research amounted to $\mathrm{N}_{72-115}$. Ammonium saltpeter was applied.

\section{Agroclimatic conditions}

The years of research differed in the hydro-thermic conditions (Figures 1,2). This allowed us to evaluate the adaptive properties of the studied varieties of oil flax to the conditions of the Cis-Urals region. The calculation of the average daily air temperature and the amount of precipitation was carried out on the basis of daily indicators of the listed parameters of the weather station in Izhevsk (Weather in Izhevsk ..., 2020).

May 2012 was characterized by the following weather conditions: precipitation amounted to $88 \%$ of the norm, or $43 \mathrm{~mm}$, the average air temperature for the whole month was $2.2^{\circ} \mathrm{C}$ higher than the long-term average. June was characterized by large $66 \%$ amount of precipitation and increase of $1.8{ }^{\circ} \mathrm{C}$ with an average air temperature per day. In the second half of the growing season (July and August), increased amount of precipitation was observed - 134-142\% of the norm and this was accompanied by an increase of the average daily air temperature by $1.1-1.3{ }^{\circ} \mathrm{C}$. Under the conditions of increased soil moisture and relatively high air temperature, relatively slow ripening of seeds occurred.

The growing season of 2013 was characterized by relatively hot and dry meteorological conditions (hydro thermic factor is $0,2 \ldots 0,8$ ). May 2013 was characterized by temperature conditions close to long-term average values, but at the same time, $54 \%$ of long-term average precipitation fell, or $25 \mathrm{~mm}$, the bulk of which fell immediately after sowing. June and July were distinguished by hot and dry weather: the average daily temperature exceeded $0.9-2.3^{\circ} \mathrm{C}$, and the amount of precipitation was $60-83 \%$ of the norm.

Hydro thermic conditions of the vegetation periods of 2014 and 2015 characterized as wet and cool in the second half of the growing season (hydro thermic factor is 1.4-2.0). May 2014 was characterized by an average daily temperature increase of $3.6^{\circ} \mathrm{C}$ and decrease of $66 \%$ of precipitation relative to the average longterm similar data. Weather conditions in June formed at the level of long-term average values with a total precipitation of $64 \mathrm{~mm}$ and average daily air temperature of $16.1^{\circ} \mathrm{C}$. Oil flax plants have found themselves in favorable conditions for growth and development. July was distinguished by an increased by $25 \%$ from the normal amount of precipitation and greater by $1.0^{\circ} \mathrm{C}$ average daily air temperature. During the period of seed maturation (August), a combination of increased average daily air temperature by $1.7^{\circ} \mathrm{C}$ and decreased on $9 \%$ amount of precipitation was observed.

In 2015, the first half of the oilseed flax vegetation (May, June) passed with increased by $2.5-3^{\circ} \mathrm{C}$ average daily air temperature and decreased on $25-35 \%$ average daily precipitation. In the second half of the growing season (July and August), decreased by 2.2 and $3.3^{\circ} \mathrm{C}$ average daily air temperature was observed, in comparison with the average annual temperature, and it was 15.7 and $13.8^{\circ} \mathrm{C}$, but the amount of precipitation was equal 
to $186-190 \%$ of the norm or 120 and $124 \mathrm{~mm}$. This delayed the ripening of varieties and harvesting (see Figures $1,2)$.

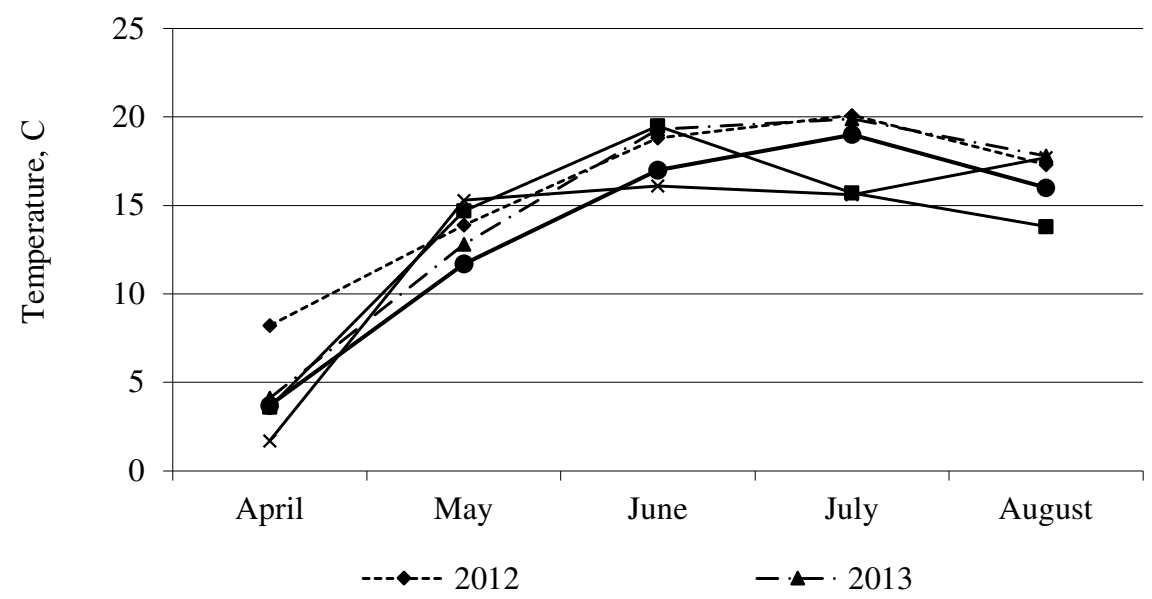

Figure 1. The average daily temperature for the growing season of oil flax (according to the Izhevsk weather station: Weather and climate, 2020)

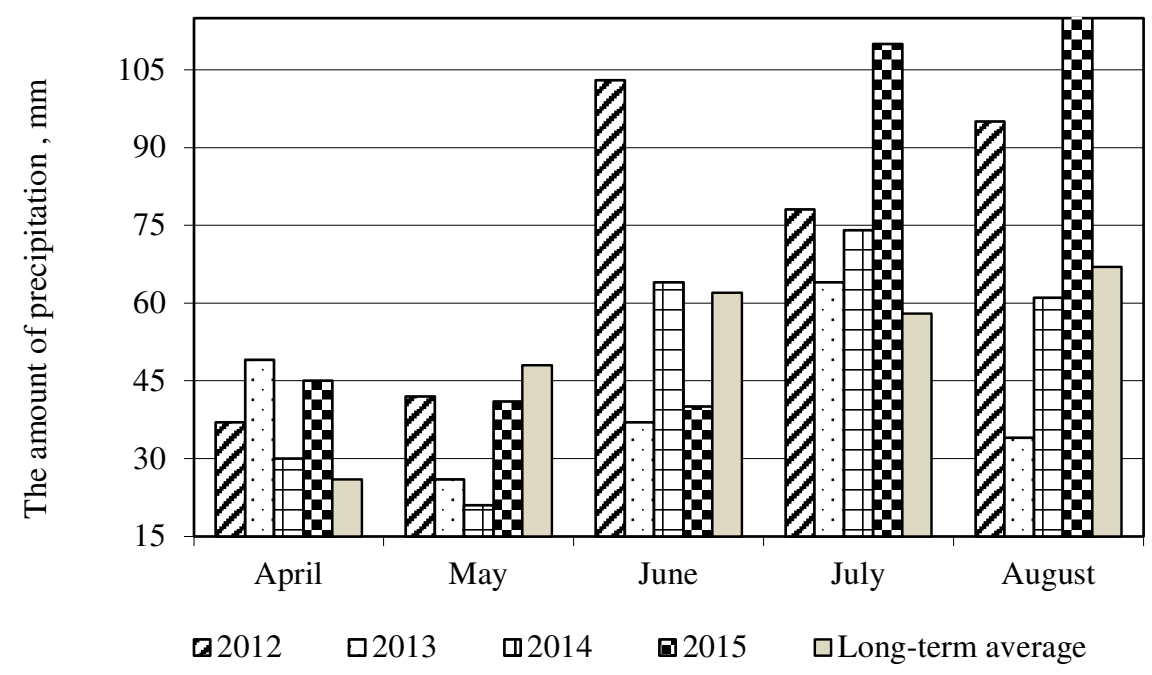

Figure 2. The amount of precipitation during the growing season of oil flax (according to Izhevsk weather station)

\section{Results}

Over the years of research, the highest average seed yield of the studied varieties of oil flax was formed under abiotic conditions in 2014 and amounted to $218 \mathrm{~g} / \mathrm{m}^{2}$ (Table 1). Abiotic conditions in other years of the study led to a decrease in the average yield of seeds of oil flax varieties: in 2012 by $104 \mathrm{~g} / \mathrm{m}^{2}$, or $48 \%$, in 2013 by $182 \mathrm{~g} / \mathrm{m}^{2}$, or $83 \%$, in 2015 by $80 \mathrm{~g} / \mathrm{m}^{2}$, or $37 \%$. Varieties of oil flax on abiotic conditions in 2012 showed diverse reaction, thus forming different seed yields. The standard variety 'VNIIMK 620' exceeded all tested varieties in productivity, having the highest seed yield of $157 \mathrm{~g} / \mathrm{m}^{2}$. The yields of the remaining studied varieties 
differed by $10-74 \mathrm{~g} / \mathrm{m}^{2}$ or $10-66 \%$ to the lower side, compared with the same index of the variety taken as a standard with LSD $0510 \mathrm{~g} / \mathrm{m}^{2}$.

Table 1. Seed yield formed in varieties of oil flax, $\mathrm{g} / \mathrm{m}^{2}$

\begin{tabular}{|c|c|c|c|c|c|c|c|}
\hline \multirow{2}{*}{$\begin{array}{c}\text { Item } \\
\text { No. } \\
(\text { No })\end{array}$} & Variety & 2012 & 2013 & 2014 & 2015 & $\begin{array}{c}\text { Average } \\
\text { for } \\
2012-2015\end{array}$ & $\begin{array}{c}\text { Deviation } \\
\text { from } \\
\text { standard }\end{array}$ \\
\cline { 2 - 6 } 1. & $\begin{array}{c}\text { 'VNIIMK 620', } \\
\text { standard }\end{array}$ & 157 & 31 & 229 & 142 & 147 & - \\
\hline 2. & 'Norlin' & 101 & 25 & 179 & 118 & 108 & -39 \\
\hline 3. & 'Voronezhsky' & 91 & 28 & 201 & 136 & 113 & -34 \\
\hline 4. & 'LM-96' & 94 & 46 & 204 & 126 & 132 & -15 \\
\hline 5. & 'N 3829' & 95 & 20 & 178 & 133 & 109 & -38 \\
\hline 6. & 'Atalante' & 118 & 47 & 210 & 156 & 134 & -13 \\
\hline 7. & 'Mo Eregor' & 114 & 31 & 203 & 153 & 128 & -19 \\
\hline 8. & 'LM-92' & 117 & 26 & 213 & 107 & 119 & -28 \\
\hline 9. & 'Clark' & 97 & 43 & 283 & 134 & 143 & -4 \\
\hline 10. & 'Culbert' & 109 & 41 & 242 & 151 & 140 & -7 \\
\hline 11. & 'Barbara' & 147 & 43 & 230 & 131 & 135 & -12 \\
\hline 12. & 'Severny' & 140 & 45 & 214 & 172 & 146 & -1 \\
\hline 13. & 'Stavropol territory' & 83 & 20 & 232 & 132 & 119 & -28 \\
\hline 14. & 'LM-98' & 128 & 26 & 220 & 134 & 132 & -15 \\
\hline 15. & 'Linda' & 117 & 48 & 229 & 112 & 129 & -18 \\
\hline 16. & 'Flanders' & 114 & 48 & 215 & 171 & 141 & -6 \\
\hline & 'Average' & 114 & 36 & 218 & 138 & 130 & -17 \\
\hline & LSD & 10 & 3 & 8 & 15 & 6 & - \\
\hline & Index of environment & -12.4 & -90.7 & 91.4 & 11.7 & & \\
\hline
\end{tabular}

Under relatively unfavorable abiotic conditions of 2013, oil flax varieties had seed yield of $20-48 \mathrm{~g} / \mathrm{m}^{2}$. 'Mo Eregor' variety got the yield of $31 \mathrm{~g} / \mathrm{m}^{2}$ i.e. at the same level as the standard. The most productive, with seed yields 10-17 g/ $\mathrm{m}^{2}$ higher than the standard variety, were 'LM-96', 'Atalante', 'Clark', 'Culbert', 'Barbara', 'Severny', 'Linda' and 'Flanders' (LSD $05-3$ g/m²). Varieties 'Norlin', 'Voronezhskysky', 'N 3829', 'LM-92', 'Stavropol Territory' and 'LM-98' were less productive, their seed yield was $3-11 \mathrm{~g} / \mathrm{m}^{2}$ lower than the seed yield of 'VNIIMK 620'.

'Clark' and 'Culbert' varieties responded to growing conditions in 2014 with increase of seed productivity on $13-54 \mathrm{~g} / \mathrm{m}^{2}$ in comparison with the productivity of the 'VNIIMK 620 ' variety with $\mathrm{LSD}_{05}-8$ $\mathrm{g} / \mathrm{m}^{2}$. All remaining experimental varieties had significantly smaller difference of seed yield which is $9-51 \mathrm{~g} / \mathrm{m}^{2}$, except 'Barbara', 'Stavropol Territory' and 'Linda' varieties, in relation to the productivity of the variety taken for control.

Under the conditions of 2015 , the best reaction of oil flax by $29-30 \mathrm{~g} / \mathrm{m}^{2}$ was the formation of seed yields of 'Severny' and 'Flanders' varieties compared to the seed yield of the standard variety 'VNIMMK 620'. Decrease of seed yields by 16-65 g/m² was observed in varieties 'LM- 98', 'LM-92', 'Norlin', 'Linda'.

On average, over 4 years of experiments it was found that in productivity none of the tested varieties significantly exceeded the standard. 'Clark' varieties from Holland and 'Barbara' from Hungary were not inferior in productivity to 'VNIIMK 620'. The rest of the studied varieties responded to growing conditions with decrease of $6-41 \mathrm{~g} / \mathrm{m}^{2}$ seed yield relative to the productivity of the standard variety with $\mathrm{LSD}_{05}-4 \mathrm{~g} / \mathrm{m}^{2}$.

As a result of the analysis of experimental data, it was found that the best abiotic conditions for the growth and development of oil flax plants were established in 2014 (index of environmental conditions $\mathrm{I}_{\mathrm{j}}=$ 
91,4), the worst in $2013\left(I_{j}=-90,7\right)$. In 2012 and 2015 the prevailing conditions occupy an intermediate position $\left(\mathrm{I}_{\mathrm{j}}=-12,4\right.$ and 11,7 , respectively).

The data from our experiments show that, most of all (by 91.5\%), the seed yield of the tested varieties of oil flax changed depending on the conditions prevailing during the period of growth and development. The genotype of the variety participated in the formation of seed productivity by $3.0 \%$, random factors by $0.2 \%$. It follows that the abiotic conditions of the growing season turned out to be the determining factors in the formation of the seed yield of the studied varieties of oil flax.

According to the yields of oilseed flax varieties (2012-2015), the parameters of ecological plasticity and adaptability were calculated and evaluated (Tables 2, 3).

Table 2. Ecological plasticity parameters of the yield of oil flax varieties (average for 2012-2015)

\begin{tabular}{|c|c|c|c|c|}
\hline $\begin{array}{c}\text { Item } \\
\text { No. } \\
(№)\end{array}$ & Variety & $\begin{array}{c}\text { Variation coefficient, } \\
\text { V\% }\end{array}$ & $\begin{array}{c}\text { Plasticity coefficient } \\
(\mathrm{bi})\end{array}$ & $\begin{array}{c}\text { Stability factor } \\
\left(\mathrm{S}^{2} \mathrm{di}\right)\end{array}$ \\
\hline 1. & 'VNIIMK 620' standard & 58.6 & 1.06 & 617.4 \\
\hline 2. & 'Norlin' & 60.0 & 0.84 & 32.2 \\
\hline 3. & 'Voronezhsky' & 64.0 & 0.97 & 125.6 \\
\hline 4. & 'LM-96' & 56.5 & 0.88 & 131.1 \\
\hline 5. & 'N 3829' & 62.8 & 0.88 & 188.2 \\
\hline 6. & 'Atalante' & 51.6 & 0.91 & 210.5 \\
\hline 7. & 'Mo Eregor' & 58.0 & 0.95 & 307.0 \\
\hline 8. & 'LM-92' & 66.2 & 1.00 & 1090.7 \\
\hline 9. & 'Clark' & 73.9 & 1.33 & 114.0 \\
\hline 10. & 'Culbert' & 61.9 & 1.12 & 400.3 \\
\hline 11. & 'Barbara' & 55.6 & 1.00 & 403.3 \\
\hline 12. & 'Severny' & 50.3 & 0.93 & 262.0 \\
\hline 13. & 'Stavropol territory' & 76.6 & 1.18 & 134.4 \\
\hline 14. & 'LM-98' & 62.5 & 1.05 & 488.0 \\
\hline 15. & 'Linda' & 59.5 & 0.97 & 359.4 \\
\hline 16. & 'Flanders' & 52.8 & 0.94 & \\
\hline
\end{tabular}

Over the years of research, significant fluctuations in seed yields were observed in all tested varieties of oil flax, the coefficient of variation was $50.3-76.6 \%$. This indicates the dependence of the variety genotype on environmental factors. 'Clark' varieties (bi=1,33), 'Stavropol Territory' (bi=1,18), 'Culbert' (bi=1,12), 'VNIIMK 620' (bi=1,06) reacted to the conditions of the year (plastic coefficient is greater than unity) more strongly and 'LM-98' ( $\mathrm{bi}=1.05)$. These are varieties of the intensive type - they react more strongly to the improvement of growth conditions, however, under adverse conditions of growth and development, their productivity decreases more strongly. Varieties 'Norlin', 'LM-96', 'N 3829' respond to changing environmental conditions less, so they can be used with extensive technologies, with obtaining the maximum return at minimum cost. The plasticity coefficient of 'LM-92', 'Barbara', 'Voronezhsky', and 'Linda' varieties is close to or equal to unity, which indicates that the change of productivity is fully consistent with the change of growing conditions.

The stability coefficient can be used for characterizing the level of yield fluctuations. The less this coefficient deviates from zero the greater the stability of the variety provides. Greater stability in seed yield is provided by the 'Norlin' variety $\left(S^{2} \mathrm{di}=32.2\right)$. This variety had significant advantages in some respects relative to many experimental varieties. Clark was the most unstable in seed yield in the years of study.

The most resistant to stress and most of all have the ability to adapt varieties 'Norlin', 'LM-96', 'N 3829' and 'Atalante' varieties are the most resistant to stress and the most adaptable. The difference between the minimum and maximum in seed yield in these varieties is the smallest $-157.0-167.0 \mathrm{~g} / \mathrm{m}^{2}$. 
Table 3. Adaptability of varieties of oil flax seed yield (average for 2012-2015)

\begin{tabular}{|c|c|c|c|c|c|c|}
\hline \multirow{2}{*}{$\begin{array}{l}\text { Item } \\
\text { No. } \\
\text { (№) }\end{array}$} & \multirow[b]{2}{*}{ Variety } & \multicolumn{2}{|c|}{ Yield, $\mathrm{g} / \mathrm{m}^{2}$} & \multirow{2}{*}{$\begin{array}{c}\text { Stress } \\
\text { resistance } \\
\mathrm{g} / \mathrm{m}^{2}\end{array}$} & \multirow{2}{*}{$\begin{array}{c}\text { Range of } \\
\text { yield } \\
\%\end{array}$} & \multirow{2}{*}{$\begin{array}{c}\text { Genetic } \\
\text { flexibility } \\
\mathrm{g} / \mathrm{m}^{2}\end{array}$} \\
\hline & & $\mathrm{y}_{2} \min$ & $\mathrm{y}_{1} \max$ & & & \\
\hline 1. & $\begin{array}{c}\text { 'VNIIMK 620' } \\
\text { standard } \\
\end{array}$ & 30.0 & 232.0 & -202.0 & 131.0 & 87.1 \\
\hline 2. & 'Norlin' & 24.0 & 181.0 & -157.0 & 102.5 & 86.7 \\
\hline 3. & 'Voronezhsky' & 27.0 & 205.0 & -178.0 & 116.0 & 86.8 \\
\hline 4. & 'LM-96' & 45.0 & 210.0 & -165.0 & 127.5 & 78.6 \\
\hline 5. & 'N 3829' & 19.0 & 181.0 & -162.0 & 100.0 & 89.5 \\
\hline 6. & 'Atalante' & 46.0 & 213.0 & -167.0 & 129.5 & 78.4 \\
\hline 7. & 'Mo Eregor' & 28.0 & 207.0 & -179.0 & 117.5 & 86.5 \\
\hline 8. & 'LM-92' & 26.0 & 216.0 & -190.0 & 121.0 & 88.0 \\
\hline 9. & 'Clark' & 41.0 & 293.0 & -252.0 & 167.0 & 86.0 \\
\hline 10. & 'Culbert' & 49.0 & 251.0 & -211.0 & 145.5 & 84.1 \\
\hline 11. & 'Barbara' & 41.0 & 233.0 & -192.0 & 137.0 & 82.4 \\
\hline 12. & 'Severny' & 44.0 & 221.0 & -177.0 & 132.5 & 80.1 \\
\hline 13. & $\begin{array}{l}\text { 'Stavropol } \\
\text { territory' }\end{array}$ & 17.0 & 234.0 & -217.0 & 125.5 & 92.7 \\
\hline 14. & 'LM-98' & 26.0 & 221.0 & -195.0 & 123.5 & 88.2 \\
\hline 15. & 'Linda' & 47.0 & 231.0 & -184.0 & 139.0 & 79.6 \\
\hline 16. & 'Flanders' & 46.0 & 218.0 & -172.0 & 132.0 & 78.9 \\
\hline
\end{tabular}

'Clark' and 'Culbert' varieties are relatively less resistant to changes in growing conditions. In 2013 which is relatively unfavorable by meteorological conditions their productivity decreased by $167 \%$ and $145.5 \%$, respectively, compared with productivity in relatively favorable 2014. Varieties 'N 3829', 'LM-92', 'Stavropol Territory' and 'LM-98' were identified as relatively the most flexible, best adapted to changing environmental conditions. Under various abiotic conditions these varieties formed the highest average seed yield of 88.0-92.7 $\mathrm{g} / \mathrm{m}^{2}$, which indicates the greatest correspondence between the genotype and environmental factors

\section{Discussion}

In the Middle Cis-Ural region, on sod-podzolic soils, among abiotic conditions, the main limiting factor in the formation of fiber flax yield is the amount of precipitation for the "herringbone" - flowering period (Maslova et al., 2018), in the formation of oil flax seed yield - the sum of the temperatures during flowering yellow ripeness (Goreeva, 2019). The most adaptive varieties of long flax and oil flax have established varieties that provide stable yield over years. According to Liebig's law, weather conditions, namely precipitation, is the main limiting factor which very often affects on flax productivity in many regions of Europe (Heller and Byczynska, 2015). In Poland the optimum soil moisture for flax should be at least $62,5 \%$. Arid conditions lead to decreasing in fiber yield by $39.7-49.3 \%$. Currently, there is progress in biotechnology of flax growing in Europe and China, two leading producers of flax fiber: classical selection methods supported by genetic engineering technologies can accelerate the efficiency of selection to increase the yield and quality of new varieties of flax (Kulma et al., 2015). In order to reduce the negative impact of drought on flax productivity, alternation of small and large ridges with full-layer mulching is recommended in China, which provides an innovative option for optimizing the hydrothermal conditions of the soil, thereby increasing the productivity and profitability of flax crops in dry semi-desert conditions (Mo et al., 2018). In Lithuania to breed new well adapted to local soil and climatic conditions flax varieties predominantly traditional selection with 
hybridization methods is used which is also applicable for Russia (Jankauskiene and Gruzdeviene, 2015). Varieties are tested on economically valuable traits, genetic flexibility, plasticity, stability.

Under the conditions of Central and Northern Italy the genotype of the variety, the cultivation zone, and vegetation conditions had a significant effect on the yield, chemical composition of flax production, and its structure (Tavarini et al., 2016). The highest seed yield of the distinguished varieties was $3.05 \mathrm{t} / \mathrm{ha}$, the yield of aboveground biomass was $6.98 \mathrm{t} / \mathrm{ha}$. The main objective of the Latvian flax breeding program is to create highly productive flax genotypes (both fibers and seeds) that well adapt to changing of environmental conditions (Stafecka et al., 2016). This allows us to divide the genotypes of flax varieties into two groups of lower and higher yields and make recommendations for production. In the Southeast Agricultural Zone of Romania (Anastasiu et al., 2016), May-June is a critical period in the consumption of moisture for development of oil flax due to the intensive growth of plants in height and branching. During this period, flax plants require more precipitation and low average daily temperature. In July-August, when seed ripening occurs, flax plants need higher average daily temperatures and small amount of rainfall. One of the significant abiotic factors in India (New Delhi), that causing stress in flax plants is drought which inhibits plant growth and development (Dash et al., 2018). A number of studies confirm that not only seed yields, but also changes in oil content depend on genotypic characteristics. In the conditions of the dry steppe zone of Northern Kazakhstan on the dark chestnut soils of the Akmola region, it was established that the formation of oil depends on the climatic conditions of cultivation and on the sum of the active temperatures during seed maturation (Gordeyeva and Shestakova, 2018). For the dry steppe zone in terms of plasticity and stability of oil content 'VNIIMK 620', 'Lirina', 'Karabalyksky 7 'varieties are highly valuable, and 'Severny', 'Biryuza', 'Kazar', and 'Ilyich' varieties are valuable.

Abiotic conditions include many factors, such as location, field topography, landscape, soil conditions, climatic factors (precipitation amount, average daily temperature and duration of the growing season), etc. Information collection of these factors, their effect on flax yield and structure indicators will allow us to calculate the regression equations for analysis, evaluation and comparison of new varieties (Jia and Booker, 2018). According to Egyptian scientists' flax productivity is also influenced by chemical factors, namely, the use of mineral fertilizers (Emam, 2019). The introduction of nitrogen fertilizers into the soil: ammonium nitrate, ammonium sulfate provides the highest yield of straw and flax seeds, compared with the yield obtained from the application of urea (Emam, 2019).

Thus, scientists from Russia and other countries, regardless of selection programs and methods of creating varieties, test the evaluation of the tested varieties for adaptability to specific soil and climatic conditions, to various abiotic factors and give recommendations to agricultural producers to improve the efficiency of the flax growing industry.

\section{Conclusions}

On the sod-podzolic soils of the Middle Cis-Urals, year conditions had a decisive influence on seed yields of the tested varieties of oil flax by $91.5 \%$, the genotype of the variety participated in the formation of the seed yield by 3.0\%. Significant variability of seed yield $(\mathrm{V}=50.3-76.6 \%)$ of the studied varieties of oil flax allows us to state that the agroecological environmental conditions had a decisive influence on this parameter. In 2014, the growth and development of oil flax plants took place under the most favorable abiotic conditions (index of environmental conditions $\mathrm{Ij}=91,4)$. On average over four years of research the same reaction to abiotic conditions with seed yield $\left(141-147 \mathrm{~g} / \mathrm{m}^{2}\right)$ was formed in 'VNIIMK 620' and 'Severny' varieties from Russia, 'Clark' varieties from Holland and 'Flanders' from Canada. Significant fluctuations in seed yields were observed in all tested varieties of oil flax. 'Norlin' from Canada, 'LM-96', 'N 3829' - from Russia and 'Atalante' from

France are the most resistant to stress and the most adaptable varieties. The most flexible variety is 'Clark' with flexibility coefficient bi equals to 1.33 . The most stable seed yield is 'Norlin' with stability factor of 32.2 . 
Varieties 'N 3829' from Russia and 'Norlin' from Canada distinguished themselves by the smallest range of seed yield. The listed varieties will provide more stable indicator in specific cultivation conditions. Varieties from Russia such as 'N 3829', 'Stavropol Territory', 'LM-98' and 'LM-92' had the best genetic flexibility, which indicates the greatest correspondence between the genotype and environmental factors.

Thus, the most suitable for cultivation in the conditions of the Cis-Urals region oil flax varieties are selected. The Russian variety 'N 3829' and the Canadian variety 'Norlin' have high resistance to stress and low yield, have a wide range of adaptive capabilities respectively. The listed varieties should be recognized as promising in terms of seed yield, their adaptation to various abiotic cultivation conditions and used as starting material in the breeding process.

\section{Authors' Contributions}

VG, EK, IF, VL, and CI contributed equally to the experimentation. EK wrote and edited the article. VG and IF equally designed and conducted the experiment. CI studied scientific literature about the topic. All authors read and approved the final manuscript.

\section{Acknowledgements}

This research received no specific grant from any funding agency in the public, commercial, or not-forprofit sectors.

\section{Conflict of Interests}

The authors declare that there are no conflicts of interest related to this article.

\section{References}

Anastasiu AE, Chira NA, Ionescu N, Stan R, Rosca SI, Banu I (2016). Oil productivity of seven Romanian linseed varieties as affected by weather conditions. Industrial Crops and Products 86:219-230. https://doi.org/10.1016/j.indcrop.2016.03.051

Dash PK, Gupta P, Jailani AK, Rai R (2018). Hydropenia induces expression of drought responsive genes (DRGs) erdl, hat, plD-delta, and zfa in Linum usitatissimum L. Indian Journal of Experimental Biology 56(10):743-749. bttp://nopr.niscair.res.in/handle/123456789/45122

Dospekhov BA (2012). The methodology of field experience (with the basics of statistical processing of research results). Book on demand, Moscow.

Eberhart SA, Russell WA (1966). Stability parameters for comparing varieties. Crop Science 6(1):36-40. https://doi.org/10.2135/cropsci1966.0011183X000600010011x

Emam SM (2019). Cultivars response of flax (Linum usitatissimum L.) to different nitrogen sources in dry environment. Egyptian Journal of Agronomy 41(2):119-131. https://dx.doi.org/10.21608/agro.2019.10947.1157

Fatykhov ISh, Goreeva VN, Koshkina KV, Korepanova EV (2014). Yield structure of oil flax varieties under the conditions of the Middle Cis-Ural region. Proceeding of the all-Russian scientific-practical conference "Innovations in science, methods and technologies". Izhevsk: Udmurt University, pp 107-110.

Fu YB, Diederichsen A, Richards KW, Peterson G (2002). Genetic diversity within a range of cultivars and landraces of flax (Linum usitatissimum L.) as revealed by RAPDs. Genetic Resources and Crop Evolution 49(2):167-174. https://doi.org/10.1023/A:1014716031095 
Gordeyeva Y, Shestakova N (2018). The influence of agroclimatic factors on the formation of oil content in flax seeds in the North of Kazakhstan. Journal of Ecological Engineering 19(3):102-105. https://doi.org/10.12911/22998993/85740

Goreeva VN, Pechnikov DN, Korepanova EV (2015). Productivity of oilseed flax VNIIMK 620 for different methods of pre-sowing and after-sowing tillage in the Middle Cis-Ural region. Proceeding of the All-Russian scientificpractical conference. Izhevsk: Izhevsk State Agricultural Academy, pp 5-11.

Goreeva VN (2019). Oil flax in the Middle Cis-Ural region: monograph. Izhevsk: Izhevsk State Agricultural Academy.

Heller K, Byczynska M (2015). The impact of environmental factors and applied agronomy on quantitative and qualitative traits of flax fiber. Journal of Natural Fibers 12(1):26-38. https://doi.org/10.1080/15440478.2013.879088

Jankauskiene Z, Gruzdeviene E (2015). Recent results of flax breeding in Lithuania. Industrial Crops and Products 75:185-194. https://doi.org/10.1016/j.indcrop.2015.07.024

Jia G, Booker HM (2018). Optimal models in the yield analysis of new flax cultivars. Canadian Journal of Plant Science 98(4):897-907. https://doi.org/10.1139/cjps-2017-0282

Kapinos AI, Leshchenko VI (2009). Variety as an element of flax cultivation technology. Bulletin of NSAU (Novosibirsk State Agrarian University) 4(12):12-19.

Khamutovsky PR, Kargopoltsev LN (2005). Early ripening fiber flax varieties of selection of the Republican Unitary Scientific Enterprise "Mogilev Regional Agricultural Experimental Station of the National Academy of Science of Belarus". Proceeding of the International scientific-practical conference "Problems of improving the technological quality of fiber flax", Torzhok, pp 49-56.

Korepanova EV, Galiev RR, Goreeva VN, Starkova IP (2017). Autumn cultivation of the soil in the formation of oilseed flax productivity in the Middle Cis-Ural region. Proceeding of the All-Russian scientific and practical conference dedicated to the 85 th birthday of Doctor of Agricultural Sciences, professor of the Department of Agriculture and Land Management Vladimir Mikhaylovich Kholzakov "Implementation of the principles of agriculture in conditions of modern agricultural production”. Izhevsk: Izhevsk State Agricultural Academy, pp 141-148.

Kulma A, Zuk M, Qiu CS, Wang YF, Jankauskiene S, Preisner M, Long SH (2015). Biotechnology of fibrous flax in Europe and China. Industrial Crops and Products 68:50-59. https://doi.org/10.1016/j.indcrop.2014.08.032.

Maslova MP, Korepanova EV, Fatykhov ISh (2018). Reaction of flax varieties to meteorological conditions of the Middle Cis-Urals. Bulletin of the Izhevsk State Agricultural Academy 55:57-66. https://izhgsha.ru/images/DOCS/Nauka/VESTNIK/Vipuski/2018/2018_2.pdf[In Russian].

Mo F, Li XY, Nju FJ (2018). Alternating small and large ridges with full film mulching increase linseed (Linum usitatissimum L.) productivity and economic benefit in a rainfed semiarid environment. Field Crops Research 219:120-130. https://doi.org/10.1016/j.fcr.2018.01.036

Potanin VG, Alenikov AF, Stepochkin PI (2014). New approach to assessing the environmental flexibility of plant varieties. Vavilovsky Journal of Genetics and Breeding 18(3):548-552. bttp://www.bionet.nsc.ru/vogis/download/18-3/17_Potanin.pdf

Rossielle AA, Hamblin J (1981). Theoretical aspects of selection for yield in stress and non-stress environments. Crop Science 21(6):943-946. https://doi.org/10.2135/cropsci1981.0011183X002100060033x

Rozhmina TA (2001). The main directions of research on the mobilization of the "National collection of Russian flax" to solve the priority problems of selection. In: Genetic resources of cultivated plants. Pp 162-164.

Shcherbakov VK (1981). The evolutionary-genetic theory of biological systems: homeostasis, the significance of the development of the theory of selection. Vestnik of Agricultural Science 3:56-67.

State register of selection achievements approved for use (2020). http://reestr.gossortrf.ru/reestr.html

Stafecka I, Stramkale D, Grauda D (2016). Estimation of yield stability for flax genetic resource using regression and cluster analysis. Research for Rural Development 15-22. http://www2.llu.lv/research_conf/proceedings2016_vol_1/docs/LatviaResRuralDev_22nd_vol1-15-22.pdf

Tavarini S, Angelini LG, Casadei N, Spugnoli P, Lazzeri L (2016). Agronomical evaluation and chemical characterization of Linum usitatissimum L. as oilseed crop for bio-based products in two environments of Central and Northern Italy. Italian Journal of Agronomy 11(2):122-132. https://doi.org/10.4081/ija.2016.735

Vaulin AV (1998). Determination of the reliability of the average long-term indicators of short-term field experiments in the processing of research results by analysis of variance. Agrochemistry 12:71-75. 
Weather and climate (2020). Weather in Izhevsk. Air temperature and precipitation. Reference and information portal "Weather and climate". http://www.pogodaiklimat.ru/monitor.php

Workshop on Agrochemistry (2008). Koloss, Moscow. https://new.znanium.com/catalog/product/445474

Zhuchenko AA (1990). Adaptive crop production (ecological and genetic basis). Stiinta, Chisinau.

Zhuchenko AA (2008). Adaptive crop production (ecological and genetic basis). Publishing House Agrorus (Vol. 1), Moscow.

Zykin VA, Belan IA, Roseev VM (2000). Spring wheat selection for adaptability: results and prospects. Reports of the Russian Academy of Agricultural Sciences 2:5-7

Zykin VA (2005). Methodology of calculating and evaluating the parameters of ecological flexibility of agricultural plants. BashSAU, Ufa, pp 100.
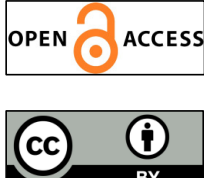

The journal offers free, immediate, and unrestricted access to peer-reviewed research and scholarly work. Users are allowed to read, download, copy, distribute, print, search, or link to the full texts of the articles, or use them for any other lawful purpose, without asking prior permission from the publisher or the author.

License - Articles published in Notulae Botanicae Horti Agrobotanici Cluj-Napoca are Open-Access, distributed under the terms and conditions of the Creative Commons Attribution (CC BY 4.0) License.

(c) Articles by the authors; UASVM, Cluj-Napoca, Romania. The journal allows the author(s) to hold the copyright/to retain publishing rights without restriction. 